\title{
Cemal Abdün Nasır İktidarında Mısır-Türkiye İlişkilerinin Türk Basınına Yansımaları (1954-1962)
}

\author{
Yrd. Doç. Dr. Şinasi SÖNMEZ*
}

\begin{abstract}
ÖZET
İkinci Dünya Savaşı'ndan sonra Türkiye'nin de içinde bulunduğu Orta Doğu'da çok büyük siyasal değişiklikler meydana geldi. Bölgede İngiltere ve Fransa eski gücünü kaybederken, ABD ve Sovyetler Birliği daha etkin güç haline geldi. Türk hükümetleri denge değişiminde, Sovyetler Birliği'nin karşısında yer alan Batı Blok'unun içinde yer alabilmek için çaba harcarken, bu süreçte Orta Doğu ülkeleri ile ilişkilerini “hür dünya” yanlısı, Sovyetler Birliği karşıtı bir söylemle düzenleme yoluna gitmiştir.

Öte yandan, 1950'lerden itibaren bölgede etkin bir siyaset gütme gayretinde olan Türkiye, Ingiltere ve ABD'nin desteğini almıştır. Bu destek Irak, Ürdün, Lübnan gibi ülkelerin yönetiminde tepki uyandırmaz; hatta onaylanırken 1952'den itibaren Musır'ın tepkisini çekmiştir. Ellili yıllarda Türkiye-Mısır İlişkileri gergin bir seyir izlerken, Türk basını bu gerginliğin nedenini Nasır ve iktidarına bă̆lamıştır. Ayrıca Orta Doğu'da Türkiye ve müttefikleri aleyhine gelişmelerin sorumlusu olarak Nasir gösterilmiştir.
\end{abstract}

Anahtar Kelimeler: Soğuk Savaş dönemi, Ortadoğu, Cemal Abdün Nasır, Basin, Muhalefet.

\section{During Cemal Abdul Nasir Governance Reflections of Egypt-Turkey Relatıons on Turkish Press (1954-1962)} SUMMARY

After World War II , tremendous political changes have happened in Middle East where Turkey is one of the countries in the region. Losing England and France their power on the region, on the contrary, United States and Union of Soviet

\footnotetext{
* Karaelmas Üniversitesi Ereğli Ĕ̆itim Fakültesi İlköğretim Bölümü.
} 
Socialist Rebuplics have gained more effective pover. The alteration of balance process, Turkish governments have been endeavoring to find a place in the Western Bloc againt to Eastern and also they have arranged their relations with other Middle East Counties according as "free world" allias, anti USSR.

On the other hand, since 1950's, with effective political efforts on the region, Turkey has been supported by England and USA. The support did not take any reaction from Iraq, Jordan and Lebanon, even it met with approval by the countries, after 1952, Egypt has given reaction the support. In the fifties, Turkey and Egypt relations has been on edge and Turkish Press pointed at Nasir's Government as the reason of the situation. Also, Nasir has been accused of all the negative situations against to Turkey and its allias in the Middle East by Turkish Press.

Key Words: Cold War, Middle East, Cemal Abdul Nasir, Press, opposition

\section{GIRIŞ}

Türkiye İkinci Dünya Savaşı'nın sona ermesiyle yeni gelişmelerle karşı karşıya kaldı. Sovyetler Birliğgi'nin savaş sonrasında Türkiye ile olan ilişkilerini yeniden gözden geçirme isteği karşısında iki ülke ilişkileri yeni bir seyir izlemiştir. Öte yandan, savaşın galipleri arasında yapılan dünya siyasetini yeniden şekillendirme planları Türkiye'yi yeni dış politika arayışlarına itmiştir. Türkiye'nin içeride ekonomik ihtiyaçlar doğrultusunda para gereksinimi, diğer yandan dışarıda sınırlarını güvence altında tutma doğrultusunda dış dünya ile olan ilişkilerini düzenleme kaygısı söz konusu arayışların yönünü belirlemiştir.

Savaşın sonlarına doğru Almanya ve bağlaşıklarının yenileceğinin belli olmaya başlamasıyla Türkiye Müttefiklere daha yakın politikalar takip etmiştir. Savaş zamanında Almanya yanlısı yayın yapan basın organlarına sansür uygulamaya başlamış bazı gruplar tahkikata uğramıştır. 1944 Mayısında resmî tebliğle Turancılar arasında tutuklamalara gidilmiş, sol yayın yapan gazeteciler de tahkikata uğramışlardır. ${ }^{1}$ Dönemin hükümeti hem Almanya hem de Sovyetler Birliği yanlısı yayınları kısıtlarken, hükümetin izleyeceği yeni politikanın da işaretini vermiştir.

Savaş sona ererken Türkiye'nin Birleşmiş Milletler'e dâhil olması için demokratikleşme yolunda adım atması gereği hissedilmeye başlanmıştır. Birleşmiş Milletler demokrasi temelli bir örgüt olarak ortaya çıkmıştır. Milli Şef İsmet İnönü 19 Mayıs 1945 'teki söylevinde çok partili yaşama geçileceği müjdesini vermiştir. ${ }^{2} 1945$ Bütçesi Görüşmeleri sırasında Celal

${ }^{1}$ Tevfik Çavdar; Türkiye'nin Demokrasi Tarihi 1839-1950, İmge Kitabevi, Ankara, 1995, s, 39-392.

a.g.e., s. 393 
Bayar ve bazı milletvekilleri hükümetin ekonomi politikalarını eleştirerek yakında bir muhalefetin ortaya çıkacağının ipuçlarını vermişlerdir. Çiftçiyi Topraklandırma Kanunu ile "dörtlü takrir" ile muhalefet partisinin temeli atılmış; 7 Ocak 1946'da kurulan Demokrat Parti ile birlikte Türkiye'nin çok partili demokratik hayatı resmî olarak başlamıştır. Dış dünyadaki gelişmeler Türkiye'nin iç politikasının yönünü ve seyrini çok partili hayata geçiş biçiminde etkilemiştir. Bir diğer önemli gelişme de Türkiye'nin kuzey komşusu Sovyetler Birliği'nin izleyeceği gerilim politikası dış siyasetin yönünü tayin etmede etkili olmasıdır.

Savaştan sonra CHP iktidarı Sovyetler Birliği’nin Boğazlar ve toprak talebiyle ile ilgili baskılarını İngiltere ve ABD ile yakınlaşma politikaları ile bertaraf etmeye çalışırken, bunu kurulan NATO ittifakına katılma çabaları ile de desteklemiştir. 1950'de iktidarı DP'ye devrederken izlenecek dış politika çizgisini de belirlemiş oluyordu. DP hükümetlerine temel politikayı yürütmek kalıyordu. Nitekim Kore'ye Türkiye'nin asker göndermesiyle ABD ve müttefikleri ile NATO ittifakı ile bütünleşmesi kolaylaşmış ardından 1952'de Türkiye NATO'ya girmiştir. ${ }^{3}$ Bundan sonra dış politikanın temel doğrultusu "hür dünya" ile hareket etmek biçiminde olmuştur.

Türkiye, Sovyetler Birliği ile olan sorunlarını NATO müttefikliği ile dengeler, ardından müttefiki olduğu İngiltere ve Fransa'nın Orta Doğu'da sömürgeleri ve Mısır gibi ülkelerle sorunlar yaşamaya başlaması, dönemin Türk hükümetlerinin de bu sorunlarda genelde iki ülkenin tarafında yer alması Türkiye'nin Kıbrıs Sorunu gibi diğer devletlerin desteğine gereksinim duyduğu konularda zor durumda bırakmıştır. Birleşmiş Milletler'deki oylamalarda Yunanistan lehine çıkan oylar, zaman zaman Orta Doğu ülkelerinden geldiği gibi, Orta Doğu'da Arap ülkeleri ile sorunlarında desteklediği İngiltere ve Fransa'nın aleyhinde oy kullandığı gerçeği ile yüz yüze gelmiştir. Üstelik bölgede bulunan halklarla Türkiye'nin tarihi-kültürel bağlarının bulunması, aynı zamanda emperyalist emellere karşı verdiği Kurtuluş Savaşı, Türkiye'den kendilerini açıkça desteklemesi yönünde beklentiler yaratmıştır. Temel politikasının içte ve dışta tam bağımsızlık olmasına, kendi sınırları dışında topraklarda emperyalist bir amaç gütmemesine rağmen, Türkiye müttefiklerinin Orta Doğu'da karşılaştıkları direniş hareketlerini bastırma girişimlerinde dolayısıyla Orta Doğu politikasında ikileme sürüklemiştir.

1955'te yapılan Bandung Konferansı'nda, Fas ve Tunus'un bağımsızlık mücadelesinde, Mısır'ın Süveyş Kanalı'nı millileştirmesinde Türkiye, Batılı ülkelerin safında yer almıştır. Oysa yakın tarihte bağımsızlık savaşı vermiş bir ülkenin sömürge ülkelerinin yanında yer alıyormuş görüntüsü vermesinin

${ }^{3}$ Soğuk savaş dönemi ile ilgili değerlendirmeler için bkz. Ayşegül Sever ; Soğuk Savaş Kuşatmasinda Türkiye, Batı ve Orta Doğu 1945-1958, Boyut Kitapları, İstanbul, 19997. 
gerekçelerini hem kendi kamuoyuna hem de bölge halklarına anlatması zor olmuştur. Dönemin hükümetlerinin belirlediği dış politika stratejisi, ilerleyen yıllarda karşılaştığı sorunları aşmada zorluklar çıkarmıştır. Aynı dönemde bağımsızlığına kavuşan ülkeler "Bağlantısızlar" adı altında Birleşmiş Milletler'de ve birçok alanda ortak hareket ederlerken, Türkiye, Kıbrıs ile ilgili oylamalarda onların oyuna muhtaç olmuştur. İktidara geldiğinde Arap ülkelerine karşı daha aktif politika izleyeceğini söyleyen DP hükümeti ileri gelenleri izledikleri aktif politika yolculuğunda bölge ülkelerinin liderleri ya da yönetimleri ile sorunlar yaşamışlardır. Örneğin Mısır lideri Nasır'ın Türkiye'de hükümet çevreleri hatta basının ileri gelen kalemleri tarafından ellili yılların sonuna kadar eleştirilere uğramıştır.

Yazının konusunu oluşturan dönemin büyük bölümü Adnan Menderes'in başbakanlığını yaptığı DP hükümetleri dönemidir. Dönemin hükümetleri komünizm propagandası, milli birlik ve beraberliğe zarar verici olarak gördüğü yayınların dışında yayınlara sürekli sansür uygulamamış, ${ }^{4}$ soğuk savaş döneminin özellikleri ne uygun olarak basının bu doğrultuda yayın yapmasını istemiştir. Genellikle iç politika çekişmelerinden dolayı gazeteciler tahkikata uğramış, ellili yılların sonuna doğru hükümete muhalefet eden gazeteciler çeşitli soruşturmalara uğramış, bazıları hapse atılmıştır. Öte yandan hükümete yakın olan gazete ve gazetecilere örtülü ödenekten para yardımı yapılmıştır. ${ }^{5}$ Bütün bunlara rağmen Demokrat Parti iktidarları döneminde gerek iktidar yanlısı gerekse muhalif yayın yapan gazete ve dergilerin sayıları azımsanamayacak ölçüdedir. Bazı gazete ve dergiler yayınlarına gördükleri mali ve siyasi baskıdan zaman zaman ara vermişlerdir. Öte yandan iç politikadaki iktidar-muhalefet çekişmesi dış politika söz konusu olduğunda ülkenin birlik ve beraberliği adına farklı görüşlerin ifadesi söz konusu olmamıştır. Bir başka anlatımla NATO müttefikliği çerçevesinde Batılı ülkelerle ya da hürriyet yanlısı ülkelerle; Sovyetler Birliği ve komünizm karşıtı müttefikliği söylemi hâkim olmuştur. Bu bakış açısı iktidar yanlısı basın ile muhalefet yanlısı basının dış politikayı bu pencereden değerlendirmesine temel oluşturmuştur. 1957 yılından itibaren iktidar ile muhalefet arasındaki görüş ayrılıklarının derinleştiğini, iktidarın muhalif basına karşı katılaştığı ölçüde farklı değerlendirmelerin dış politika konusunda da ortaya çıkmaya başladığını gözlemlemekteyiz. Kuzey Afrika'da bulunan milletlerin bağımsızlık mücadelesinin dünya kamuoyunu işgal etmeye başlaması üzerine özellikle muhalefet yanlısı basında bazı yazarların, Türk hükümetinin bu bağımsızlık mücadelelerine duyarsız kaldığı yönünde eleştirilere rastlanmaktadır. Mısır-Türkiye ilişkilerinin sorunlu bir döneme girmeye başlaması Türk basınında Nasır aleyhtarlığı

${ }^{4}$ Mustafa Yılmaz, Yasemin Doğaner; Cumhuriyet Döneminde Sansür 1923-1973), Siyasal Kitabevi, Ankara 2007, s.20.

${ }^{5}$ Rasih Nuri İleri; Örtülü Ödenek, Scala Yayıncılık, İstanbul, 1996, s.156-157. 
konusunda adeta ağız birliği yaratmıştır. Nasır'ın 1952'de askerî darbe ile yönetime gelmesi, yönetime geliş biçimiyle eleştiri konusu olmamıştır. Nasır'ın Arap milliyetçiliğini temel alan politikası, diğer Arap ülkeleri ve İngiltere ile sorunlar yaşamaya başlaması, aynı zamanda Türkiye'nin Orta Doğu politikasıyla ters düşmesi, Türk basınında Nasır'ın diktatörlüğüne vurgu yapan eleştirilerin çoğalmasına neden olmuştur.

Bağdat Paktı'nın kurulması, paktta İngiltere'nin yer alması, Arap Birliğini oluşturan ülkeler arasında görüş farklılıklarını derinleştirirken, Türkiye'nin Ürdün, Lübnan, Suriye gibi ülkelere diplomatik baskılar yapması Türkiye-Mısır ilişkilerine olumsuz yansırken, Türk basını tarafından Nasır'ın kişiliğinde Mısır'ın izlediği siyaset eleştirilmiştir. Mısır'ın Bağdat Paktı'na tepkileri bölge ülkelerinde ve Mısır'da önemli yankılar uyandırmıştır. Fakat Bağdat Paktı'nın bölgede beklenen etkiyi yaratmaması, muhalefet yanlısı basın tarafından Menderes hükümetlerinin genelde dış politikayı, özelde ise Türkiye'nin Ortadoğu politikasını başarısız olarak nitelendirmesine neden olmuştur. İç politikadaki görüş farklılıkları dış politikaya da aynı ölçüde yansımıştır.

1952'de darbe ile işbaşına gelen askerî yönetimde Cemal Abdün Nasır etkin bir konumda bulunurken; 1954'te yönetimi tamamen ele geçirmiştir. İzlediği Arap milliyetçiliği siyaseti, bölgede Araplar üzerinde tesirler bırakırken, bölge ülkelerinde yöneticilerin korkulu rüyası olmuştur. Türkiye bölgede Sovyetler Birliği'nin etkisini bertaraf etmek için İngiltere ve Fransa'yı destekleyen bir siyaset izlerken, ABD'nin bölgede daha etkin bir rol oynaması için çalışmıştır. Nasır'ın tamamen hâkim olduğu Mısır dış politikası, bölge ülkelerinin izlediği politikalarda kendini hissettirirken, bazı iktidarlar değişmiş, Türkiye'nin izlediği Ortadoğu siyaseti Türk basını tarafından eleştirilmeye başlanmıştır.

Nasır'ın ülkesinde gerçekleştirdiği değişiklikler, Orta Doğu siyaseti, Arap milliyetçiliği üzerine görüşleri 1962'den itibaren Yön dergisi tarafından yazı dizisi olarak yayınlanırken, başarılarından övgüyle söz edilmiş, Yön Dergisi gibi bazı yayın organlarında "Başkan Nasır” biçiminde söylenmiştir.

\section{Demokrat Parti'nin Ortadoğu Politikast}

Demokrat Parti 1950'de iktidara geldikten sonra Arap ülkeleri ile daha sıkı ilişkiler kuracağının işaretlerini Dışişleri Bakanı Fuat Köprülü’nün ağzından açıklamıştır. O dönemde Orta Doğu'da İngiltere ve Fransa'nın desteğiyle kurulmuş ve ayakta duran monarşi yönetimleri iş başında idi. Dönemin Türk hükümeti mevcut yönetimlerle ilişkileri yakınlaştırmaya çalışırken, monarşilerin arka arkaya devrilmesi, bu ülkelerde halk arasında yükselen Arap milliyetçiliği eski yönetimlerle işbirliği yapan hükümetlere de tepkiler doğurmuştur. Soğuk Savaş döneminin başlangıç yılları diyebileceğimiz 1950'li yıllarda Orta Doğu coğrafyası kaynayan kazan 
durumundadır. Bölgenin sömürgeci devletleri İngiltere ve Fransa'nın etkin gücü bölgeden tasfiye edilirken yerlerini $A B D$ ve Sovyetler Birliği almaya başlamıştır. Bu rekabet ortamın da yardımıyla ülkelerde yönetim değişiklikleri, İngiltere ve Fransa'nın Süveyş Bunalımı örneğinde olduğu gibi bölgede eski etkinliğini kaybetmesi, Arap ülkeleri arasında kendi aralarında çekişmeler, yine aynı ülkeleri ortak paydada birleştiren İsrail düşmanlığının getirdiği işbirliği ellili yılların belli başlı gelişmeleridir.

Türkiye ve Irak'ın 1955'te bir askerî ittifak oluşturması düşüncesi Mısır ve lideri Nasır'ı oldukça tedirgin etti. Irak Başbakanı Nuri El Said'i kurulacak ittifaktan vazgeçirme girişimi sonuçsuz kaldı. Nasır'ın görüşü bölgede güvenliği sağlamak Batı'dan çok bölge ülkelerinin görevi olmalıydı. Nuri'nin görüşü ise bölge ülkelerini Sovyetler Birliği tehdidinden ancak Batı'nın yardımıyla korunabileceği yönündeydi. ${ }^{6}$ Sonuçta Bağdat Paktı kurulurken Nasır ve Nuri Sait arasında çekişme propaganda savaşına dönüştü. Bu savaşta Türk hükümeti ve basını Nuri Sait'in tarafında yer alırken, Nasır'ın aleyhinde haberler ve yorumlar gittikçe artıyordu.

\section{Bozulan Türkiye-Mısır İlişkilerinin Basına Yansımaları}

Türkiye'nin Mısır ve onun askerî darbeyle işbaşına gelmiş lideri Nasır ile olan uzun süreli çekişmesi gazete ve dergilerin sık sık Nasır, Mısır ve Arap devletleri ile ilgili değerlendirmelerine konu olmuştur. Türkiye'nin Bağdat Paktı ile bölgede öneminin artması Mısır'ı endişelendirmiş, Türkiye ile Mısır arasında büyükelçilerini geri çekmeye kadar gidecek bir çekişmenin nedeni olmuştur. Akis, gelişmenin başladığ 1 tarihte, Mısır'ın tepkisini ihtilal subaylarının bir ihtiyat siyaseti güttüğünü, Mısır'1 Batı ile Doğu arasında hakem rolü oynayabilecek bir bloğun başına geçirmek istediklerini, bunu sağlayabilmek için Arap ülkeleri arasında mekik diplomasisi yürüttüklerini yazıyordu. Mısır'ın asıl amacının Ankara-Karaçi mihverine bağlanmak isteyen Arap ülkelerine baskı yapmak ${ }^{7}$ olduğu düşüncesini ileri süren dergide Türkiye-Mısır arasındaki çekişmenin Türk basınına yansımasını okuyoruz.

Mısır'ın Ocak 1954'te Kahire Büyükelçisi Hulusi Fuat Togay'1 istenmeyen adam ilan ederek sınır dışı etmesinden ${ }^{8}$ sonra Türkiye-Mısır ilişkileri biraz daha zor bir döneme girmiştir. Aynı yılın Temmuz ayında Türkiye Arap Ülkelerindeki büyükelçilerini Ankara'da toplayarak meydana gelen gelişmelerle ilgili bilgilenmiş, izlemesi gereken politikayı gözden geçirmiş̧tir. Dönemin gazeteleri bu toplantıyı Türkiye'nin Ankara-Karaçi

${ }^{6}$ Adid Davişa; Arap Milliyetçiliği Zaferden Umutsuzluğa, (Çev. Lütfi Yalçın), Literatür Yayınları, İstanbul 2004, s. 144-145.

${ }^{7}$ Dünyada Olup Bitenler; Akis; 17 Temmuz 1954, s.11-12.

${ }^{8}$ Bkz. Mahmut Dikerdem; Ortadoğu'da Devrim Yllları (Bir Büyükelçinin Anıları), İstanbul, 1977, s.71. 
hattında kurulacak komünizm tehlikesine karşı güvenlik ittifakına Arap ülkelerini katmak için nasıl bir yol izleneceği görüşmesi olarak değerlendirmişlerdir. ${ }^{9}$ Türkiye, oluşturulacak olan Bağdat Paktı'na bütün Arap ülkelerinin katılmasını arzularken, İngiltere de paktın üyesidir. Oysa Mısır gibi diğer Arap ülkelerinin bir kısmının İngiltere ile sorunları vardır. $\mathrm{Bu}$ yüzden, oluşacak böyle bir pakta Irak'tan başka bir Arap ülkesi katılmayacaktır. Bu sorun uzun süre Türkiye-Mısır geriliminin nedeni olacaktır. Irak ile Türkiye arasında imzalanacak olan Orta Doğu Paktı'nın Irak Meclisi'nde onaylanmasını Zafer Gazetesi birinci sayfadan verirken Başbakan Adnan Menderes'in konu ile ilgili açıklamasına geniş şekilde yer verilmiştir. Menderes, Suriye ve Lübnan'ın Irak ile Türkiye arasında yapılacak anlaşmaya anlayışla yaklaş̧ı̆̆ını belirtirken, Mısır'ın aynı anlayışı göstermemesini üzüntüyle karşıladığını söylemiştir. ${ }^{10}$ Gazetenin yazarlarından Mümtaz Faik Fenik, Menderes'in demeçlerini değerlendirirken Türkiye ile Irak arasında yapılacak bir antlaşmanın sadece iki ülkeye değil, insanlı̆̆a da hizmet edeceği şeklinde yorumlamış; Başbakan Menderes ile Irak Başbakanı Nuri Sait Paşa'nın büyük katkıları olduğunun altını çizmiştir." ${ }^{11}$ Bir diğer yazar Burhan Belge ise Mısır'ın gelişmeler hakkındaki olumsuz tavrını irdelemiştir.

Yine Zafer Gazetesi Arap Birliği başbakanlarının Kahire'de toplanmasını birinci sayfa haberi olarak verirken Mısır'ın Türkiye- Irak antlaşmasına neden karşı olduğu yönündeki açıklamalarına yer vermiştir. ${ }^{12}$ Aynı tarihli gazetede dış politika yazarı Mümtaz Faik Fenik Türkiye-Mısır ilişkilerinin çıkmaza girmesini iki yakın arkadaşın anlaşmazlığına benzeterek, sürekli hatalar yapan kişiyi Mısır'a benzetirken, Türkiye'yi aklıselim düşünerek uyarıcı rolünü üstlenen diğer arkadaşa benzetmiştir. Türkiye'nin Mısır'a sürekli dost eli uzatmasına rağmen küskün kaldığını, sebebinin Irak'ın Türkiye ile dostluk anlaşması imzalarken Arap Birliğine danışmaması olduğunu ileri sürmüştür. Oysa bölgede iki ülke arasında dostluk anlaşmalarının yapılmasının Mısır'ın lehine olduğunu, Mısırlı yöneticilerin bu durumu hesaba katmadıkları şeklinde değerlendirmiştir. ${ }^{13}$

Türkiye'nin Orta Doğu Paktı çerçevesinde bütün Arap ülkelerini toplayabileceği düşünülürken; Mısır bu pakta şiddetle karşı çıkmıştır. Türkiye; İngiltere, İran, Irak, Pakistan'dan başka katılan ülke olmamıştır.

\footnotetext{
${ }^{9}$ Mücahit Topalak; Ankara Toplantıs1; Akis, 17 Temmuz 1954, s. 11.

${ }_{10}$ «Başvekil'in Mühim Beyanatı", Zafer, 8 Şubat 1955,s.1. Gazete birinci sayfasının da ayrıca Türkiye-Irak paktı imzalandığı takdirde Mısır'ın Arap Güvenlik Paktı'ndan çıkacağı haberini vermiştir. Yine dikkat çekici bir haberin başlı̆̆ "Türkiye Lider" şeklindedir. Başbakan Adnan Menderes ve Dışişleri Bakanı Fuat Köprülü İtalya’yı ziyareti dolayısılyla yapılan temasları yorumlayan Newyork Times gazetesinde "Türkiye Lider" başlığı altında bir makale yayınlandığını haber olarak vermiştir.

${ }^{11}$ Mümtaz Faik Fenik; "Menderes Açık Kalple Konuştu”, Zafer, 8 Şubat 1955, s1.

${ }^{12}$ “" Arap Birliği Başvekilleri Dün Toplandı”, Zafer, 23 Ocak 1955, s.1.

${ }^{13}$ Mümtaz Faik Fenik; “Türkiye ve Mısır”, Zafer, 23 Ocak 1955, s.1.
} 
Bağdat Paktı'nın imzalanması gazetelerde birinci sayfadan en önemli haber olarak geçmiştir. ${ }^{14}$ Mümtaz Faik Fenik antlaşmanın imzalanmasının iki ülkeye dışarıdan gelecek tehlikelere karşı bir kader birliği yaptıracağını, Misır ve Suudi Arabistan gibi ülkelerin baltalamak istemelerine rağmen gerçekleşmesinin önemine değinmiştir. ${ }^{15}$

Ahmet Şükrü Esmer, Bağdat Paktının Orta Doğu'da beklenen etkiyi yaratmadığını, Türkiye'nin Kıbrıs sorunu ve 6-7 Eylül olayları nedeniyle dünya kamuoyunda zor durumda kaldığını yazmıştır. 1955 yılına ilişkin değerlendirmelerinde ayrıca ekonomik sorunların Türkiye'nin dış politikasını etkilediğini, ülkenin dış borçlarını ödemede zorluklarla karşılaşmasına rağmen dünyadaki gelişmelere tepkisiz kalmamasını olumlu olarak değerlendirmiştir. ${ }^{16}$

\section{Nasır'ın Siyasetine Odaklanan Basının Eleştirileri}

Mısır Başbakanı Nasır, El Cumhuriye gazetesinde Türkiye ile ilgili bir makale yayınlar. Makale iki ülke arasında meydana gelecek olumsuzlukların kaygısını haber vermekte, Nasır'ın izleyeceği siyasetin belirtilerini taşımaktadır. O tarihte bölgede Irak, Suriye, Ürdün, Suudi Arabistan, Lübnan, Misır, Kuveyt, Birleşik Arap Emirlikleri gibi nüfusunun çoğunluğunu ya da bütünü Arapların oluşturduğu bağımsız devletler mevcuttur. Nasır'ın bölge ile ilgili değerlendirmesinde bu devletlere yer verilmezken, Arap-Türk kardeşliği ön plandadır. Geçmişte ve şimdi Araplarla Türklerin kardeş uluslar olduğunu, Türklere ve Araplara gelen kötülüklerin aynı düşmandan geldiğini belirtmiştir. Türk ve Arap vatanının Şark’ın iki kıtası olduğunu, Türkiye’nin yönünü Avrupa'ya çevirmiş bir Asya devleti olduğunu; Türkçenin ise Latince yazılsa bile Arapça ile aynı sözlüğün ortak lafzı olduğunu, kendilerinin de dili kabul ettiğini ileri sürmüştür.

İki ulusun tarihinin ortak olduğunu, bu ortaklığın Buhara ve Tebriz'de başladığını, oradan Bağdat, Musul'a ve Anadolu'ya ulaştığını yazmıştır. Ortak düşmanın sömürgeciler olduğunu, onların İzmir'de Şam'da Kahire'de

${ }^{14}$ « Türk Irak Paktı İmzalandı;”, Zafer, 25 Şubat 1955, s.1.

Zafer gazetesi haber başlığının altında paktın imzalanmasıyla ilgili geniş bir yorum yapılmıştır. "Orta Doğuya emniyet ve çok mesut bir istikbal getirecek olan Türk-Irak paktına dün gece Türkiye adına Başvekil Adnan Menderes ve hariciye vekili Köprülü, Irak adına da Başvekil Nuri Said ve Hariciye Vezir vekili imza koydular."

"Türk Irak müdafaa paktı coskun tezahüratla ve ittifakla tasdik olundu. Haricive vekili Prof. Fuat Köprülü iki dost memleket arasında addolunan anlaşmanın esaslarını belirterek paktın Ortadoğu ve dünya sulhu bakımından ehemmiyetini izah etti" Zafer, 27 Şubat 1955, s.1.

${ }^{15}$ Mümtaz Faik Fenik; "Bağdat Paktının İmzası”, Zafer, 25 Şubat 1955, s,1.

${ }^{16}$ Ahmet Sükrü Esmer; "Diş Politika", Ulus, 1 Ocak 1956

Esmer; “Mısır'da Yeni Rejim”, Ulus, 20. 01.1956. Esmer yazısında Nasır'ın iktidara geliş biçimini, önceki yönetim ile Nasır'ın yönetimini karşılaştırmıştır. 
ortak masa etrafında Türkleri ve Arapları dışarıda bırakarak kararlar aldıklarını tespit etmiştir. Sömürgeciler her ne kadar bu iki ulusu, tellerle, setlerle bölgelerde ortak akrabalığı yok etmeye çalışsa da bunu başaramayacağını, çünkü soy ve gelenek olarak birbirine karışık olduğunu iddia etmiştir.

Türkiye'yi tehdit eden kuvvetlerin, Arapları da tehdit ettiğini, bu nedenle Arapların kurtuluşunun Türklerin de kurtuluşu olacağını, ortak düşmanların mevcut hükümetlerden beklentilerinin boşa olduğunu ileri sürmüştür. ${ }^{17}$

Nasır daha o tarihte Orta Doğu'da siyasetini Arap milliyetçiliği üzerinden, Batı karşıtı bir yönde izleyeceğinin işaretlerini vermiştir. İzleyeceği siyaseti Arap kamuoyuna anlatırken, Türk hükümeti ve kamuoyuna bir mesaj niteliği taşımaktadır. Fakat iki ülkenin Orta Doğu'da izlediği politika Nasır'ın sahip olduğu görüşlere paralel gitmemiştir.

Bağdat Paktı'nın kurulması ile birlikte Türkiye ve Mısır basınında birbirleri ile ilgili olumsuz yazı ve yorumlar görülmeye başlanmıştır. Türk basını Nasır'ı diktatör olarak yansıtırken Nasır milliyetçiliğinin Orta Doğu'da huzursuzluk ve tehlike kaynağı olduğunu, milliyetçiliği yeni tanıyan Arap ülkelerini olumlu bir yöne sevk etmeyeceğini iddia etmiştir. 1957'de Kahire Radyosu'ndan Batılı ülkelerin özellikle ABD'nin aleyhinde yayınlar yapılırken, Amerikanın Sesi Radyosu da karşı yayın yapmaktadır. Bu suretle radyoda Arap milliyetçiliğinin Nasır gibi diktatörlerin elinde yanlış yönlere saptırıldığını, bu yanlışlığı düzeltmenin de mümkün olmadığı şeklinde değerlendirmiştir. ${ }^{18}$

Orta Doğu ülkelerinden bazıları ve Nasır ile ilgili yapılan olumsuz değerlendirmelere ilişkin eleştiriler Menderes iktidarına muhalif olan gazete ve dergilerden gelmeye başlamıştır. Aydemir Barkan, Türkiye'nin Bağdat Paktı'na Arap ülkelerinin katılmasını ısrarla istemesinin, hatta Ürdün, Lübnan, Suriye gibi ülkelere baskı yapmasının Mısır'ın tepkisini çektiğini, bu tepkinin sonucunda Mısır ve Suriye'nin Birleşik Arap Devleti kurduğunu ileri sürmüştür. Devamında, Suriye'nin Hatay ile ilgili sorunları sürdürmesi, Lübnan'daki karışıklıklara Batılı ülkeler ve ABD'nin müdahalesini Türkiye'nin ısrarla istemesi ve desteklemesi, Süveyş Kanalı'nı Mısır'ın millileştirmesiyle İngiltere ve Fransa ile olan çatışmasında Türkiye'nin bu iki devleti desteklemesi Mısır-Türkiye ilişkilerinin gerginlik noktaları olduğu şeklinde değerlendirmiştir. Yazar basının ve iktidarın tutumunun değişmesine ilişkin şu görüşleri ileri sürmüştür:

\footnotetext{
17 “Mısır Başvekili'nin Çok Değerli Bir Makalesi”; Zafer, 09,12.1954.

18 "Dünyada Olup Bitenler: Orta Doğu", Akis, 2 Şubat 1957, s. 12-13.
} 
"Son Haftalarda Arap memleketlerine bilhassa Misır'a karşı iktidarın ăgzı de ğişmiştir. Onunla beraber birtakım "tahsilâtlı" basınımız bu memleketlere, liderlerine ve davalarına karşı uzun yıllardır takındı̆̆ menfi, küçümseyici tavrını terk etmek ihtiyacını duymuştur. Spor temasları ve çeşitli resepsiyonlar vesilesiyle tekrar edilen bu hava değişikliği programı hadiseleri yakından takip etme ğe meraklı olanlar için hayli ĕglenceli ve garip sahneler arz etmektedir. Bu havanın ne kadar suni olduğunu anlamak için iki ay evvelki gazetelere göz atmak kâfidir. Bu memleketlerin gerek halklarına, gerek liderlerine gerek giriștikleri mücadelelerine daha pek kısa bir müddet önce nasıl cephe aldığımızı düşünecek olursak bu ani "makam" değişikliğini izah etmek için makul ölçüler içinde sebepler bulmak güç olacaktır. $^{19}$

Ayrıca Mısır'ın Sovyetler Birliği ve Çin'den silah temin etmek için yaptığı siyasi manevraların Nasır'ın marifeti ile olduğu yolunda yorumlar yaparken, gelişmelerin Batı'nın aleyhine olduğu şeklinde yorumlar gazete ve dergi sayfalarında yer almıştır. ${ }^{20}$

Nasır liderliğindeki Mısır'ın 26 Temmuz 1956'da Süveyş Kanalı'nı devletleştirmesi Batılı ülkelerde olduğu kadar Türk basınında da beklenmedik bir olay olarak karşılanmıştır. Assuan Barajı'nın inşası için gerekli krediyi bulamayan Nasır kanalın millileştirmesiyle elde edilecek gelirle ihtiyacı olan parayı sağlamış olacaktır. Batılı ülkelerin verdikleri notaları ve diğer gelişmeleri aktaran $A k i s^{21}$, dış politika yazarları aracılığıyla da Süveyş Kanalının statüsünü ve önemine dikkati çekmiştir. ${ }^{22}$ İlgili 24 ülkenin Londra'da soruna çözüm bulmak amacıyla toplanmasını haber olarak verirken, Rusya'nın Mısır'ı destekleyeceğine dikkati çekmiştir. ${ }^{23}$ yazarı belirtilmeden yapılan bir yorumda Nasır'ın izlediği politika karışında Batı'nın hareketsizliğini 20 yıl önceki Almanların Ren Havzası'nı işgal etmesi karşısındaki tutumuna benzetmiştir. Bu durumun Nasır'a cesaret verdiğine dikkati çekmiştir. ${ }^{24}$

Türk basınında bazı yazarlar tarafından iktidarın Orta Doğu'da izlediği politika üzerinden eleştiriler gelmeye başlamasına rağmen, Nasır ve Mısır üzerine yapılan eleştirilere Moskova ve komünizm konuları eklenerek

\footnotetext{
${ }^{19}$ Aydemir Balkan; “Arapları Artık Aldatabilir miyiz?” Akis, 27 Temmuz 1957, s. 17.

${ }^{20}$ «Dünya'da Olup Bitenler: Misır, Silah Peşinde”Akis, 9 Haziran 1956, s.21

21 "Dünyada Olup Bitenler: Kabına Sığmayan Diktatör", Akis, 4 Ağustos 1956, s.11.

${ }^{22}$ Dr. İlhan Faik; Süveyş Kanalı'nın Hukuki Hikayesi, Akis, 4 Ağustos 1956, s.12-13.

${ }^{23}$ Dünyada Olup Bitenler: 24'ler Konferans1, Akis, 11 Ağustos 1956, s.14.

24 "Nasır Kime Güveniyor", Akis, 18 Ağustos 1956, s.13. Dergi başka bir sayısında Londra'da toplanan konferansın etkili bir sonuç alamamasını konu etmiştir. Mısır'ın konferansa katılmamasının hukuki gerekçelerini açıklayarak, ABD’nin İngiltere ve Fransa'nın sert tepki vermesini engellediğini, Kanalın idaresinin Birleşmiş Milletlerin emrinde bir komisyona verilmesini istediğini yazıyordu. Mısır'ı destekleyen ülkeler ise kanalın Mısır'ın idaresinde bir kumpanya tarafından işletilmesini istediğine dikkati çekiyordu. "Dünyada Olup Bitenler: Süveyş, Fare Doğuran Dağlar”, Akis, 1 Eylül 1956, s.14-15.
} 
devam etmiştir. Örneğin Tek Parti Dönemi'nin bakanlarından Şükrü Kaya ${ }^{25}$ Nasır ile ilgili görüşlerini Sovyetler Birliği'nin Orta Doğu'da güttüğü gizli emellerine eklemleyerek görüşünü açıklamıştır. Bölgedeki gelişmeler konusunda Türk devlet adamlarını uyararak, gelişmeleri dikkatle izlemelerini isterken, ülkenin çıkarları açısından durumun nezaketine dikkati çekmiştir. Bağdat Paktı'nın kuruluşuna Türkiye'nin liderlik etmesinin bölgede çıkarları açısından zorunluluk olduğunu, bunun kanıtının Nasır'ın Türkiye'nin konumunu kıskandığını, pakta katılacak olan diğer Arap ülkelerini engellediğini, hatta pakt aleyhine tahrik ettiğini belirtmiştir. Bütün bu gelişmelerin Mısır'ın ve bölgede bazı ülkelerin ekonomik potansiyellerini Moskova'nın ipoteği altına aldığını, Moskova'dan aldı ̆̆ı silahların İsrail karşısında bir başarı sağlamadığını öne sürmüștür. Moskova'nın amacının Batılı büyük devletleri kendisiyle ortak bir politika izlemeye mecbur ederek, "Şark Meselesi'nde" olduğu gibi "Düveli Muazzama" konseptini kurmak, vaktiyle kullandı ̆̆ı Slavlık, Ortodoksluk ideali yerine şimdi de komünizm ideolojisini kullanarak kaleyi içinden fethetmek olduğunu yazmıştır. Mısır'da komünizmin koyu milliyetçilik, medeniyet ve yabancı düşmanlığ 1 taassubuyla birleştirilerek genç ve münevver subaylara halk tabakalarına yayılmaya çalıșıldı̆̆ını, komünizm faaliyetlerinin idaresinin bütün dünyada Moskova'dan yapıldığını, Suriye ve Mısır'daki bu faaliyetlerin de muhtemelen bu merkezden idare edildiğine dikkati çekmiştir. ${ }^{26}$

Dönemin yazarlarının Orta Doğu değerlendirmeleri Sovyetler Birliği karşıtlığına odaklandığından, Nasır'ın izlediği Arap milliyetçiliği siyasetinin bölge halkı üzerinde etkisine eğilme gereği duymamaları, Nasır'ın milliyetçi politikalarını yeterince değerlendiremediklerini göstermektedir. Türk basınının Nasır'ın bölge halkı üzerindeki milliyetçilik etkisini değerlendirebilmeleri için Irak'ta yapılacak askerî darbe ve Lübnan'da muhalefetin Cumhurbaşkanı Chamoun'a karşı direniş̧ini görmeleri gerekecektir.

\section{Türkiye'nin Dış Politikasına Muhalif Basının Tavrı}

Bağdat Paktı ve Balkan Paktı'nın dış politikada beklenen başarıya ulaşamaması, hatta bölgede yeni gerginliklere ve gelişmelere yol açması, Türkiye'de özellikle muhalefet yanlısı yayın yapan gazetelerde yazarlar tarafından sık sık dile getirilmiştir. Hükümetin icraatlarını dış politika üzerinden eleştiren, bazı yazarlar, dış politikadaki başarısızlıklar karşısında muhalefetin yeterince tepki vermemesini de yazılarında söz konusu

${ }^{25}$ Şükrü Kaya (1883-1959) Atatürk'ün yakın çalışma arkadaşlarındandır. Ali Fethi Okyar, İsmet İnönü Hükümetlerinde Tarım, İçişleri, Dışişleri bakanlıkları yapmıştır. Hürriyet ve Cumhuriyet gazetelerinde yazarlığın yanı sıra çeşitli kitaplar yazmış aydın bir devlet ve siyaset adamıdır.

${ }^{26}$ Şükrü Kaya; “Görüşler: Orta-Doğu Hakkında Rus Notaları ve Cevapları”, Hürriyet, 17 Haziran 1957. s. 2. 
etmişlerdir. Örneğin Bülent Ecevit, Demokrat Parti hükümetlerinin dış politikadaki başarısızlığı ve muhalefetin sessizliğini demokratik ülkelerde görülmeyecek bir durum olarak değerlendirmiştir. Türkiye'de diş siyasetin tartışma üstü tutulursa başarılı olunacağı kanısının, iktidarın dış siyaset alanında yanlış yollara gittiğinde uyaracak bir araçtan yoksun bıraktığını, bu anlayışın ülke çıkarlarına zarar verdiğine dikkati çekmiştir. Ecevit eleştirilerinin devamında hükümeti dış politikanın her alanında başarısız ilan ederken, ayrıca eleştiriye tahammülünün olmadığına dikkati çekmiştir. NATO'nun Türkiye'nin güvenliği ile ilgili kanadının kırık olduğunu, Balkan Paktı'nın kendisinden bahsedilmemesinin daha münasip bir hale gelmiş olduğunu, Bağdat Paktı'nın, üç yanı dostlarla çevrili bir halde Demokrat Parti iktidarına devredilen Türkiye'nin "tehlikelerle çevrili" hale gelmesini önleyemediği yolunda tespitler yapmıştır. İktidara geldiklerinde Müslüman âleminin liderliğini ele almak iddiasıyla yapılan girişimlerin Türkiye'yi Orta Doğu'da Birinci Dünya Savaşı'ndan beri görülmedik ölçüde yalnız bıraktığını ileri sürerek iktidarı bu alanda da tamamen başarısız ilan etmiştir. ${ }^{27}$

Ecevit, ABD üzerinden Batılıların Orta Doğu politikasını da eleştirmiştir. Mısır ve liderine ekonomik ve askerî konularda destek veren ABD'nin desteğini çekmesini, Arap dünyasında Sovyetler Birliği ve yandaşları tarafından Batı aleyhine bir koz olarak kullanıldığına dikkati çekmiştir. Batılı ülkelerin de Arap-İsrail anlaşmazlığında Arapların yanında yer alırken, İngiltere ve Fransa'nın İsrail'i desteklemeye başlamasının Arap kamuoyunda olumsuz sonuçlar yaratacağını, Türkiye'nin de bu değişken politikalardan uzak kalması gerektiğini yazmıştır. ${ }^{28}$ Aynı gazetenin bir başka yazarı Hüseyin Cahit Yalçın, bölgede meydana gelen gerginliklerde, Batılı ülkelerin karşı karşıya olduğu sorunlarda Türkiye'nin arada kalmış bir görüntü sergilediğini, Atatürk döneminden sonra Türk dış politikasının iyi yönetilemediğini ileri sürmüştür. ${ }^{29}$ Ecevit bir başka yazısında Ortadoğu ülkelerinde etkili olan Arap milliyetçiliğini konu edinmiş ve Türkiye'nin milliyetçilik anlayışı ile Arap milliyetçiliğinin farklılıklarına değinmiştir. Ona göre yurt kavramına sıkı sıkıya bağlı kalan Atatürk milliyetçiliğine karşın, Arap milliyetçiliğinin geniş bir coğrafyaya yayılan Arapları hedef aldığını, Arap kültürüne bağlı bütün topluluklara yönelerek ırk, dil, din bağlamından hareketle amacına ulaşmak istemektedir. Bu politikanın yabancı olmadığına, Batılıların Arapları Osmanlılara karşı kışkırtmak için

${ }^{27}$ Bülent Ecevit; "İktidar ve Muhalefet”, Ulus, 20 Aralık 1957, s.3. Ecevit Başka bir yazısında Türkiye'nin Ortadoğu siyasetin yeterince açık olmadığına dikkati çekmiștir. Bölge ülkelerinin iç sorunlarında taraf olmaması gerektiğini, hatta hiç karışmaması gerektiğini belirtmiştir. Böyle bir anlaşın geliştirilmesi için de bölge siyasetinin ana hatlarının yeniden belirlenmesinin gerekli olduğunu vurgulamıstır.

${ }_{20}^{28}$ Bülent Ecevit; "Ortadoğu Çıkmazı", Ulus; 5 Ocak 1957, s. 3.

${ }^{29}$ Hüseyin Cahit Yalçın; "Batı İli Doğu Arasında Türkiye", Ulus, 14 Şubat 1957, s.1. 
kullanıldığına, Osmanlı idaresi bölgede yıkıldıktan sonra aynı anlayışın bizzat Araplar tarafından Batılılara yöneltildiğine okuyucularının dikkatini çeken Ecevit, bu anlayışın sonucunda hiçbir Arap ülkesinin kendi başına milli bütünlüğünü koruyacak duruma gelemediğini, aynı nedenle Arap ülkelerinin bağımsızlıklarını sağlam temeller üzerine oturtamadığını yazmıştır. ${ }^{30}$ Türk hükümetinin ise bütün bu farklılıkları hesaplamadan Orta Doğu liderliğine soyunduğunu düşünen yazar, Türkiye'nin bu liderliği İngilizlerin yardımıyla gerçekleştirmeye çalışmasının bölge gerçekleriyle bağdaşmadığı gibi, dış siyaseti başarısız kıldığ 1 görüsşündedir. ${ }^{31}$

Benzer eleştiriler Akis Dergisi yazarlarından Aydemir Barkan'dan gelmiştir. Hükümetin dış politikasını eleştirirken, içişlerinde hiçbir konuda hükümetle anlaşamadığ anlamsızlığına değinmiştir. Demokratik ülkelerde iç politika ile dış politikanın birbirinden ayrılmadığına, hatta dış politikanın iç politikada belirleyici bir rol aldığına dikkati çekmiştir. Dış politikada farklı görüşleri savunmanın vatana ihanetle eşdeğer kabul edilmesinin diktatörlükle yönetilen ülkelere özgü bir anlayış olduğunu yazmıştır. Oysa iktidarın milli birlik havasını kurnazca bir yöntemle muhalefete baskı aracı olarak kullandı ğını, yaratılan havanın etkisi ile muhalefet mensuplarının iktidara bu konularda telaşlı bir yakınlaşma içine girdiğini iddia etmiştir. Atatürk'ün Türkiye'ye çizmiş olduğu kutsal yolun bilerek ya da bilmeyerek ihmal edildiğini, özellikle bu tutumun Bandung Konferansı'ndan sonra meydana geldiği yönündeki suçlamalarını şu cümlelerle tamamlamıştır:

"Zaman zaman içeride olduğu gibi dışarıda da Atatürk inkılâp ve prensiplerine aykırı ahbaplıklar kurulmuştur. Bu gün bilerek ya da bilmeyerek yapılan hatalar anlaşıldıkça, fiyaskolar meydana çıktıkça "müşavir" ve "mütehassıslar" sürgüne gönderilmiş, fakat hasarlar olduğu gibi kalmuştır. Şimdi ise yanlış hesapların "Băgdat”tan döndürülmesine mezbuhane bir gayretle çalışmaktadır. Fakat aynı iktidarla bunu başarmak artık hem çok geç hem de çok güçtür." 32

Akis dergisinin hükümetin dış politikasını eleştirmesi esasen 1956 yılından itibaren başlamıştır. Dergi dış gelişmeleri "Dünyada Olup Bitenler" bölümünde değerlendirirken, Türk hükümetinin politikalarını da değerlendirmiştir. Haber ve değerlendirme niteliğindeki yazıların yazarı belirtilmemiştir. Dergide diş politika makalelerini çoğunlukla Aydemir Balkan yazmıştır. Balkan 1956 yılından itibaren Menderes hükümetinin izlediği dış siyaseti başarısız olarak değerlendirmiştir. Balkan Paktı'nı ve

${ }^{30}$ Ecevit; "Arap Milliyetçiliği ve Türkiye"

${ }^{31}$ Ecevit; a.g.m. s.3. Başka yazılarında görüşlerini açıklamıştır. Bülent Ecevit; "Arap Milliyetçiliği ve Batılılar", Ulus, 15 Mart 1957, s.3. Bu yazısında da Türk milliyetçiliği ile Arap Milliyetçiliğinin karşılaştırmasını Batılı ülkelerden de örnekler vererek yapmıştır.

${ }^{32}$ Aydemir Balkan; "Dış Politikada Vazifeler” Akis, 20 Temmuz 1957, s.21. 
Bağdat Paktı'nı Türkiye'ye sağladığı yararlar açısından yetersiz olarak değerlendirirken, özellikle Orta Doğu ülkelerinde Türkiye aleyhine gelişen kamuoyuna dikkati çekmiştir. Kıbrıs konusunda İngiltere'nin çıkarları doğrultusunda politika izlemenin sadece İngiliz çıkarlarına hizmet ettiğini görmenin ve bir politika değişikliğine gitmenin şart olduğunu yazmıştır. ${ }^{33}$

Akis, muhalefet partileri içinde seçmenin en çok oyunu alan CHP'nin dış politika konusunda hükümete ciddi eleştiriler yapmaya başladığını ve muhalefetin bu tutumunu olumlu karşıladığını yazarken, ülkenin çıkarları açısından da olumlu bulmuştur. Derginin değerlendirmesine göre muhalefetle iktidarın dış politikada birleştiği tek nokta Türkiye'nin Batı'nın bir parçası olduğu, iktidarın izlediği diğer konulardaki dış siyasetini ciddi eleştiriler getirdiği şeklindeydi. İktidarın birinci hatası hükümetin dış gelişmeler konusunda muhalefeti bilgilendirmediği yönündeydi. CHP'nin iktidarın dış politikasını eleştirirken Tek Parti Dönemi'nden kalan “Dış politika tabudur" anlayışını da kapı dışarı ediyordu. ${ }^{34}$

Türkiye'nin dış politikasında Kıbrıs'ın önemli yer işgal etmeye başlamasıyla birlikte muhalif yazarların hükümete karşı eleştirileri daha da artmıştır. Birleşmiş Milletler de Kıbrıs ile ilgili bir oylamada müttefik Irak'ın Yunanistan lehinde oy kullanması Akis tarafından Türkiye'nin Orta Doğu'da sultanlarla kurduğu ittifakın iflası olarak değerlendirilmiştir. Orta Doğu ülkelerinde görevli Türk diplomatlarının buralarda meydana gelen değişimleri, halkın Türkiye ile ilgili duygu ve düşüncelerini bilmemesini büyük bir zaaf olarak değerlendirmiştir. Bu ülkelerde yöneticilerle halkın arasında uçurumlar olduğunu Türk temsilcilerinin bir an önce görmesi gerektiğine dikkati çekmiştir. ${ }^{35}$

Doğan Avcıŏglu Orta Doğu'daki durumu dünyada 1945'ten bu sürece kadar olan gelişmelerin 1şığında değerlendirmiştir. İngiltere ve ABD petrol şirketlerinin çekişmesi sürerken Sovyetler Birliği'nin bir güç olarak ortaya çıkışını Orta Doğu ülkeleri açısından değerlendirmiştir. Bölgedeki çıkarları açısından Arap Birliği'ni önce İngiltere'nin desteklediğini, ABD'nin Arap milliyetçiliğini perde arkasından desteklediğini, Cumhuriyetçilerin işbasına gelmesiyle komünizmle mücadeleyi ön plana almalarından dolayı bölgede İngiltere'nin etkinliğine bir süre daha göz yumduğunu yazmıştır. Avcıoğlu, İngiltere'nin Irak, İran'daki petrolleri kontrol ederken, Misır'da askerlerini çekmek pahasına Nasır'la iyi geçinmeyi denediğini, aynı dönem içinde ABD'nin hep temkinli kaldığını ileri sürmüştür. 1945'ten 1957'ye kadar gelişmeleri değerlendirirken Bağdat Paktı'na gelinen süreci, ABD'nin paktın dışında kalmasının nedenlerini açıklamıştır. İzlenen politikalarda ABD'nin

\footnotetext{
${ }^{33}$ Aydemir Balkan; "Dostları Azalan Bir Memleket", Akis, 10 Mart 1956, s.14

${ }^{34}$ "Yurtta Olup Bitenler", Akis, 15 Şubat 1958, s. 9.

35 "Dış Politika: Akıntıya Kürek", Akis; 5 Nisan 1958, C. XII, Sayı 204, s.10-11.
} 
pakta katılmamakla, pakt dışında kalan, karşı çıkan Arap ülkeleri ile özellikle Nasır ile iyi geçinmeyi denediğini ve çıkarları açısından başarılı olduğunu öne sürmüştür. Yazar, Mısır lideri Nasır'1 "Mısır diktatörü” olarak nitelendirmiştir. ${ }^{36}$

Irak'ta meydana gelen hükümet darbesinden sonra, ABD ve İngiltere'nin Lübnan'a asker çıkarmaları basında geniş yankı uyandırırken, Kim Dergisi Orta Doğu'da Batılı ülkelerin yıllardır sürdürdüğü yanlış politikalardan ders çıkarmadıklarını, yine aynı yanlışa devam ettiklerini ileri sürmüştür. Bu yanlış politikadan Mısır lideri Nasır'ın kârlı çıktığını ABD ve İngiltere'nin görmesi gerektiğini, bölgede yaşayan insanların büyük çoğunluğunun Nasır'a sempati duyduğunu yazmıştır. ${ }^{37}$

Mısır -Suriye'nin birleşerek Birleşik Arap Cumhuriyeti adı altında bir devlet haline gelmeleri üzerine, kralları Haşimi ailesinden olan Ürdün ve Irak da birleşme kararı almıştır. Mısır Suriye'nin birleşerek Birleşik Arap Cumhuriyeti adını alması ve tek devlet olmasını Akis, dünya basınında yapılan değerlendirmeleri aktararak vermiştir. Birleşmenin Arap kamuoyunda sevinç gösterileriyle karşılandığını, Lübnan'da yasak olmasına rağmen gösteriler düzenlendiğini, Ürdün Kralı Hüseyin'in ise son derece endişeli olduğunu aktarmıştır. Yemen'in iki ülkenin birleşmesini olumlu karşılarken bu birliğe Yemen'in de katılacağını ilan ettiğine, sınır komşusu olmamalarına rağmen Yemen'in isteğinin Arap dünyasını temelinden sarstı̆̆ına işaret etmiştir. Dergi birleşmenin Arap dünyasında uyandırdığg heyecanın önemine dikkati çekerken, Arap Birliği'nin yıllardır etkili olamayıșı, sağlam bir birlik görüntüsü vermemesi konuşulurken iki ülkenin birleşerek tek devlet olması, Yemen'in birleşmeye gönüllü olduğunu açıklaması Araplar arasında Nasır'ın kahramanlaşmasına yol açtığını belirtmiştir. Böylece Nasır, yıllardır Arapların tek bir devlet olması gerektiği yolunda ikna edemediği Ürdün, Irak ve Suudi Arabistan'ın krallarına meydan okuduğuna dikkati çekmiştir. Öte yandan Nasır, halkın gözünde yönetim biçimi olarak cumhuriyeti bu monarşilere karşı bir silah olarak kullanmayı da ihmal etmezken, onlardan farkını ortaya koyduğu görüşüne yer vermiştir. New York Times gazetesinde yapılan değerlendirmeye yer veren Akis kurulan birliğin ve yönetimin Cumhuriyet olmasının iyi bir gelişme olduğunu fakat bir kişinin egemenliğinde oluşacak bir meclisin ne kadar demokratik olacağının tartışmalı olduğunu, öte yandan diğer rejimlerle kıyaslayarak her şeye rağmen olumlu olduğu yorumuna yer vermiştir. ${ }^{38}$ Batı'nın kaygısı yeni kurulan devletin Sovyetler Birliği ile yakın işbirliği yapmasıdır. O dönemde Birleşik Arap Cumhuriyeti'ne başlangıçta ABD'den bir tepki gelmemiştir. ABD, iyi ilişkiler içinde olduğu monarşileri

\footnotetext{
${ }^{36}$ Doğan Avcıŏlu ; «Bağdat Paktı Meselesine Dair », Akis, 19Ocak 1957, s. 14-15.

37 "Yanlışlıklar Komedisi", Kim, 25 Temmuz 1958, s.7.

38 "Dünyada Olup Bitenler", Akis, 15 Şubat 1958, s. 19.
} 
kızdırmama yolunu seçerken Sovyetler Birliği'nin etkisinden uzak tutmak ve petrol sahalarını kontrolünden çıkarmama siyasetini izlemiştir. Öte yandan Lübnan'da çıkan iç karışıklıklar nedeniyle Lübnan Cumhurbaşkanı Chamoun, Türkiye ve Irak'ın müdahale etmesini istemiştir. Irak Başbakanı Nuri Sait, Lübnan'daki karışıklığa müdahale için Irak'ın doğusunda bulunan General Kasım'ın komutasındaki askerî birlikleri ülkenin batısına sevk etmeye karar verdi. ${ }^{39} 14$ Temmuz 1958 günü ordu Bağdat'tan geçerken Nuri Sait ve Faysal'ın sonunu getiren darbeyi yaparak Cumhuriyet'i ilan ettiler.

Doğan Avcıoğlu ABD’nin Eisenhower Planı ile Sovyet tehdidine karşı dünya ülkelerini koruma amacında olduğunu, Sovyetlerin ise "emperyalizm" karşıtlığı adı altında yardım planları geliştirdiğini, Nasır'ın bu durumda her iki ülkenin sürdürdüğü siyasetten yararlanarak Orta Doğu'da kendi kontrolünde bir Arap emperyalizmi geliştirmeye çalıştığı şeklinde değerlendirmiştir. ABD'nin Bağdat Paktı'na girmemesinin, Orta Doğu'da meydana gelen gerilimin, hatta Nasır tarafından bölgede yaratılacak bir sıcak çatışmanın sebebi olduğunu ileri sürmüş̧tür. ${ }^{40}$

Türkiye açısından 1958 yılının başlıca önemli dış olayı; Kıbrıs Sorunu'nda uluslar arası kamuoyunun Türk tezinin yanında olmamasıdır. Özellikle Birleşmiş Milletler'de yapılan oylamalarda Bağdat Paktı ülkelerinden Irak'ın Türkiye'nin aleyhine oy vermesi dikkat çekilen bir konudur. ${ }^{41}$ Türkler adanın taksimi tezini savunmaktadır. Kim dergisi Kıbrıs Türk Kesimi'nin lideri Fazıl Küçük'ün resmini kapak yaparken 'İngiltere, $\mathrm{Ne}$ Yapmak İstiyor? ${ }^{42}$ başlığını yine dış kapakta vermiştir. Dergide, Kıbrıs Sorunu'nun başlangıcından itibaren bilgi veriliyor, Kıbrıs'ta izlediği politikanın yanlışlığına işaret edilmiştir. Kim, Fazıl Küçük ile ilgili bilgiler verirken, "İngiltere Yanlış yolda", "Kaynayan Kazan", "Huzura Veda", "Bir Liderin Portresi”, "Milli Birlik", "Tarih", "Türk Politikası", "Ya Taksim Ya Ölüm”, "Kıbrıs Bizimdir" gibi başlıklarla soruna değiniyordu. " ${ }^{43}$ Ayrıca dış politika yazarı Özcan Ergüder Kıbrıs politikasında başarı kazanılabilmesi için, Türk hükümetinin muhalefetle birlikte hareket etmesinin yararının yanı sıra, uluslar arası ilişkilerde tarihi deneyimi olan Ana Muhalefet Partisi olan CHP'nin genel başkanı İsmet İnönü ile birlikte basın toplantısı düzenlemesinin dış dünyada da yankı uyandıracağına dikkati çekiyordu. ${ }^{44}$ Nihayet yazarın öne sürdüğü milli birlik görüntüsü bir hafta sonra

\footnotetext{
${ }^{39}$ Fahir Armaoğlu; 20. Yüzyıl Siyasî Tarihi (1914-1980), Türkiye İş Bankası Yayınları, Ankara, 1989, s.512.

${ }^{40}$ Doğan Avcioğlu; "Orta Doğudaki Soğuk Harp”, Akis, 9 Şubat 1957, s.17.

41 "Dış Politika: Şu Müslüman Kardeşler”, Akis, 29 Mart 1958, s.9.

42 "Fażl Küçük, Ya taksim Ya Ölüm” Kim, Sayı: 3, 13 Haziran 1958.

${ }^{43}$ "İ Iç Olaylar", Kim, 13 Haziran 1958, s.5-16.

${ }^{44}$ Özcan Ergüder; "Kıbrıs", Kim, 28 Haziran 1958, s.9.
} 
gösteriliyor, dönemin dışişleri bakanı Fatin Rüştü Zorlu, İsmet İnönü ile bir görüşme gerçekleştiriyordu. ${ }^{45}$

Dönemin basınının dikkati çektiği diğer bir konu, Türkiye'nin dışarıdan, özellikle ABD'den kredi arayışında olması, muhalefet yanlısı basının sayfalarında eleştiri konusu olmuştur. Türkiye'nin zamanı gelen borçları ödeme sıkıntıları, bütçede meydana gelen açıklar, dönemin Menderes Hükümeti'ni yeni kredi arayışlarına itiyordu. ABD'nin dıșında Almanya ve Japonya gibi ülkelerden kredi olanaklarını araştıran hükümet üyeleri ve bu ülkelere gönderilen heyetle ilgili olarak muhalif dergiler "Dolar Peşinde" 46 başlığında olduğu gibi eleştirel haber ve yorumlar yapiyorlardi.

Irak'ta meydana gelen hükümet darbesi ve sonrasında gelişen olaylar sonucunda Nasır'ın Orta Doğu'da oynadığı rolün önemine basın bir kez daha sayfalarını ayırmıştır. Irak'ta askerî darbenin yapılması zaman açısından da çok anlamlıdır. 14 Temmuz 1958'de Bağdat Paktı devlet başkanları İstanbul'da karşılanmaya hazırlanırken, sabah saatlerinde emniyet müdürlüğünde görevliler BBC radyosundan Irak’ta bir hükümet darbesi olduğunu dinlerken, pazartesi gecesi Bağdat Radyosu bir tebliğ yayınlayarak, darbenin neden yapıldığına ilişkin, ülkesini ve dünyayı bilgilendiriyordu. Bu bildiri Türk basınında şöyle yer almıştır:

"1. Yeni Irak Cumhuriyeti Birleşik Arap Devletlerinin taraftarı olup, diğer Arap Müslüman memleketleri ile tam bir işbirliğine hazırdır.

2. Müteveffa başbakan Nuri Sait Paşa ${ }^{47}$ 'nın tanımadı $\breve{g}$ Birleşik Arap Devletleri ve bu devletlerin lideri olarak Nasır resmen tanımaktadır.

${ }^{45}$ İç Olaylar: Kıbrıs’İnönü- Fatin Fatin Rüştü Görüşmesi”, Kim 30 Haziran 1958, s. 4-8.

46 "Dış Yardım", Akis, 12Nisan 1958, s.21.

${ }^{47}$ Nuri Sait Paşa; “ Öldüğünde 69 yaşında idi. Irak'ın tek hâkimi, Ortadoğu'da tek batılı taraftarı Arap lideri idi. Ortadoğu Nuri Said ile Başkan Nasır arasında bölüşülmüştü.” Hayat hikâyesi şöyledir: “Annesi Türk Olan Nuri Sait 1888'de doğmuş ailesinin tek erkek çocuğudur. Bağdat'ın ileri gelen ailelerinin birinin çocuğu olarak onun düşünebileceği en şerefli meslek askerliktir. İstanbul'daki harp akademisine hazırlık olmak üzere Bağdat'taki askerî mektebe yazıldı. 13 yaşında İstanbul'a gelerek askerî okula yazıldı. Mülazımevvel olarak mezun olup Bağdat'a dönmüştür. İran sınırında görev yaptıktan bir süre sonra Erkânı Harbiye okulunu okumak için tekrar İstanbul'a dönmüştür. Savaş çıtı̆̆g için okulunu bitirmeden cepheye yollanmıştır. Orduda Arap milliyetçiliği fikri ile tanışmıştır. Arap milliyetçiliği, ordudaki terfi kıskançlı̆̆ının da etkisiyle Osmanlı düşmanlığı ile şekil kazanarak, kurulan gizli örgütlerde aktif görevler almıştır. Örgüt çalışmaları açığa çıktığ vakit İstanbul'dan kaçarak Basra'ya gitmiştir. İngilizler tarafından Hindistan'a esir kampına gönderildikten iki yıl sonra, Şerif Hüseyin'in ayaklanmasını duyan Nuri Sait, İngilizlerle işbirliği yapar ve ayaklanmaya katılır. İngiliz Lawrence hatıralarında ondan cesur bir Arap lideri olarak bahseder. Ateşkes antlaşmasından sonra Irak'a Faysal Kral atanmıș, Nuri Sait kurmay başkanı olarak görev almıştır. İngilizlerle işbirliği yaparak Irak'ın en nüfuzlu insanı oldu. 1930 yılında başbakanlığa getirildi. Tam 13 defa başbakan olarak atandı. Bir süre aradan sonra 1954 yılında son defa iktidara geldiğinde ülkedeki 18 gazeteyi kapatmıș, bütün partileri lağvetmiş, komünistlerin çoğunu hapse attırmıştı. Bundan sonraki seçimlerde Nuri sait hep oyların çoğunluğunu almıştır. 1955'te Bağdat Paktını'nın kuruluşunda Nasır'ın görüşme 
3. Onatlı ordu subayı başlıca askerî ve sivil makamların başına getirilmiştir.

4. Birçok subaylar ikramiye ile tekaüde sevk edilmişlerdir.

5. İhtilal muvaffakiyetle sona erdiğine göre bundan sonra düzen bozucu nümayişlere veremsi hüviyete sahip olmayan herhangi bir insanın silah taşımasina müsaade edilmeyecektir.

6. Halktan yabancı elçilikler ve Bağdat'ta oturan yabancılara bir zarar vermemeleri istenmektedir." ${ }^{\prime 4}$

İlk iki maddeden de anlaşılacağı üzere Irak'ta darbe yapan subaylar açıktan Nasır'ı desteklemektedir. Yayınladıkları tebliğin ilk iki maddesini doğrudan Nasır ve Birleşik Arap Cumhuriyeti'ne ayırmaları Orta Doğu'da Nasır'ın etkisinin ne boyutlarda olduğunu da göstermektedir. Bu darbeden sonra Irak Bağdat Paktı'ndan çıkacak, Orta Doğu'daki liderlik rekabetinde Nasır, Menderes'in bir kalesini daha düşürecektir. Darbe'den sonra İngiltere ve ABD, Ürdün ve Lübnan'a asker sevk etmişlerdir.

Irak'ta ordunun darbe yapmasından sonra Türk basınında değerlendirmeler gecikmemiştir. İngiltere ve ABD'nin Lübnan ve Ürdün'e askerî müdahalelerde bulunma girişimlerini eski müstemlekecilik anlayışını yıkamadıklarını gösterdiğini, halkın Orta Doğu'da Batı karşıtlığını kışkırttığını iddia etmişlerdir. Ergüder, Batılı ülkeler tarafından izlenen politikadan bir tek Sovyet Rusya'nın memnun olduğunu ileri sürmüştür ${ }^{49}$. Benzeri görüşleri Bülent Ecevit de dile getirmiştir. ${ }^{50}$ Yine aynı dönemde Lübnan'a müdahale için İncirlik'e konuşlanan ABD askerlerinin görevleri bitince burayı boşaltmaları gerektiğini yazıyordu. ${ }^{51}$ Yazıda, ABD askerlerinin Türk askerleri ile karşılaşmalarında keyfi davranışlardan kaçınmaları uyarısını yaparken, Türk gazetecileri Amerikan üssüne almamalarını eleştirmiştir. Ne var ki Amerikan askerleri İncirlik üssünden henüz gitmiş değillerdi. Coşkun Kırca, ABD ile Türkiye'nin Sovyet tehdidinden dolayı müttefik olması gerektiğini, müttefikliğini NATO çerçevesinde tutmak gerektiğini, İngiltere, Fransa ve ABD'nin Orta Doğu'da izledikleri politikanın yanlışlarına Türkiye'nin kesinlikle ortak olmaması gerektiğine dikkati çekmiştir.

isteğini reddetmiş, Batılı ülkeler ve Türkiye ile işbirliğinden ülkesi adına çok şeyler beklemiştir. 195815 Temmuz Salı sabahı ülkesin radyosunda askerî marşlar eşliğinde "Yaşasın Başkan Nasır" anonsları yapılırken, o canını kurtarmak için gizlice kaçarken fark edenler tarafından linç ediliyordu." "Olaylar: Sir Nuri”,Kim, 18 Temmuz 1958, s. 4-5-6-7.

48 "Irakta Cumhuriyet", Kim, 18 Temmuz 1958, s.4.

${ }^{49}$ Özcan Ergüder; "Yanlışlıklar Komedisi", Kim, 25 Temmuz 1958, s.7.

${ }^{50}$ Bülent Ecevit; “ Arap Milliyetçiliği ve Batı”, Kim, 25 Temmuz 1958, s.10-11.

${ }^{51}$ Coşkun Kırca; “ Türkiye ve Birleşik Amerika”, Kim, 12 Eylül 1958, s. 16. 


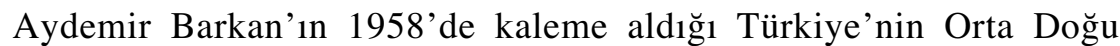
politikası ile ilgili yazısında olduğu gibi, artık muhalif basının hükümetin dıș siyasetini eleştirdiğini gösteriyordu. Diğer yandan diktatör olarak nitelenen Nasır'ın Orta Doğu'da sürdürdüğü politikanın başarılı ve haklı olduğu yönünde hatırlatmalar yapıyordu. Gelinen durumdan DP hükümetlerini ve yandaşı gazeteleri sorumlu tutuyordu. Mısır ile ilgili değerlendirmesi bütün Türk basınının tutumunu eleştirir nitelikteydi.

"Süveys tecavüzünden dolayı bütün dünya saldıranları takbih ederken anlaşılmaz bir uysallık ve sadakatle Ingiltere ve Fransa'nın yanında yer alan sadece Türkiye olmuştur. Mısır'ın çürümüş iç rejimini temizleyen ve sömürü̈cülere karşı mücadeleye girişen genç liderlerin davaları, Mustafa Kemal'in memleketinde, bir alay ve istihza konusu yapılmıştır. İhtilal Türkiye'sinin de ayn ihtirasl yollardan kırk yıl evvel bin bir badireyle geçtiği unutulmuş, haklı bir davayı yıkmak isteyen menfaat gruplarıla beraber hareket edilmiştir. Şimdi bu devletlerden mi gerçek bir dostluk göreceğimizi santyoruz?

Suriye'ye karşı tatbik edilen iktisadi ablukayı tasvip etmiş, yetmişlik milliyetçi liderlere komünist damgası vurmuşuzdur. Ortadoğu'da Ingiliz menfaatlerine cephe alan bütün vatansever liderleri Kremlin uşakliğ ile itham etmiş, hele Irak'ta petrol menfaatleri halk düşmanı mütegallibe paşalarla ittifak yapmış, kütleler üzerindeki baskılarına dolayısıla hizmet etmişizdir."

Yazı özetle, 1958'de Türk dış politikasının Orta Doğu'da bir dönemin sonuna geldiğini ortaya koymaktadır.

Irak İhtilalından sonra, Nasır'ın bölgedeki itibarı artarken, Mısır'ın İngiltere ve Fransa ile olan Süveyş anlaşmazlığı görüşmeler yoluyla çözüm yoluna girmiş, Mısır'ın bu ülke temsilcileri ile görüşmeleri basına olumlu gelişmeler olarak yansımıştır. ${ }^{53}$ Mısır'ın diğer Arap ülkeleri ile olan ilişkileri Nasır'ın ülkeler ve yönetimleri üzerinde emperyalist etkisi ${ }^{54}$ çerçevesinde değerlendirilmeye devam etmiştir. ${ }^{55}$ Habeşistan'da meydana gelen bir hükümet darbesinin arkasında Nasır'ın olabileceği şüphesi, basına Nasır'ın etkisinin ne kadar etkili olduğ ${ }^{56}$ yorumunun yapılmasına neden olmuştur. ${ }^{57}$

${ }^{52}$ Aydemir Barkan; “Arap Kardeşlerimiz Masalı”, Kim, 14 Kasım 1958, s. 28.

53 «Dış Olaylar: Araplar", Kim, 23 Ocak 1959, s.2.

54 "Diş Olaylar: Araplar", Kim, 21 Ağustos 1959, s.26-27.

55 "Dış Politika: Arap Dostların Sonuncusu", Akis, 7 Mayıs 1959, s.13.

56 "Dünyada Olup Bitenler: Habeşistan", Akis, 19 Aralık 1960, s.27.

${ }^{57}$ Habbeșiștan Kralı Haile Selasiye Brezilya'yı ziyareti sırasında Veliaht Asfa ile Kraliyet Muhafız alayının tertibi ile bir hükümet darbesi düzenlenir. Selasiye darbe haberini alır almaz yaptığı ziyareti yarıda keserek ülkesine döner. Hükümet darbesini bertaraf ederek tekrar yönetime hâkim olur. Akis dergisi darbenin dıs destekleyicileri arasında Nasır'ın olabileceğini Kralın Batı yanlısı bir politika izlemesiyle açıklar. "Gerçekten bütün Arap dünyüsono tarafsızlık bayra ̆̆ altında vekendi etrafinda Toplamak isteyen Nasır'ın 
27 Mayıs Askerî Müdahalesi'nden sonra, Türkiye'nin siyasal ve ekonomik durumunu ele alan Forum dergisi, yeni yönetimin dış politikada esaslı değişikliklere gitmesi yönünde tavsiyelerde bulunmuştur. Türk dış politikasının İkinci Dünya Savaşı'ndan sonra dünyada meydana gelen değişikliklere ayak uyduramadığını, Sovyetler Birliği'nin tehdidine maruz kaldığını, Batı'nın etkisinde bir dış politika izlemek zorunda kaldığını ileri sürmüştür. Bu etkinin Bandung Konferansı'nda Türkiye'yi sömürgeci devletlerin sözcüsü durumuna düşürdüğünü, Cezayir sorununun, bu görünüşü silmek için bir fırsat olduğunu yazmıştır. İngiltere'nin Orta Doğu'da emellerinin çok tartışıldı ğı bir sırada, Bağdat Paktı'nın kurulması Türkiye'nin bu ülke ile müttefik olmasını, Arapları kuşkulandırdığını, Türkiye'nin Orta Doğu sorunlarını bu pakt çerçevesinde değerlendirmesini dış politika açısından bir talihsizlik olarak değerlendirmiştir. Arap milliyetçilerinde paktın gerçek gayesinin bütün Arap milletlerini yeniden İngiliz nüfuzu altına koymak olduğu kanısını uyandırdığı şeklinde değerlendirmiştir. Irak İhtilali'nden sonra Türk dış politikasını yöneten bazı sorumluların Bağdat Paktı'nı Orta Doğu'daki milliyetçilik hareketlerine karşı kullanmak yolundaki eğilimlerinin paktın son itibar kırıntılarını da alıp götürdüğü yönünde eleştiriler getirmiştir. ${ }^{58}$ Dergi geçmiş dönem hükümetlerinin dış politikasını eleştirirken, yeni yönetimin izleyeceği dış politika ile ilgili olarak, Batılı ülkelerin yanında yer almakla beraber Asya ve Afrika ülkelerinin oluşturduğu Tarafsız Ülkeler bloğuna önem vermesi gerekliliğini vurgulamıştır.

Forum, 27 Mayıs 1960 sonrasını yeni bir dönem olarak ele alırken, dış politika üzerinde görüşlerine bir sonraki sayısında yer vermiştir. Türkiye'nin en önemli dış politika sorununun dünya devletleri arasında yeri olduğunu belirttikten sonra "Tarafsızlar" denilen çoğunluğunu Asya ve Afrikalı devletlerin oluşturduğu üçüncü bir kuvvetin ortaya çıktığını, bu ülkelerin milletlerarası ilişkilerde önemli bir rol oynadığına dikkati çekmiştir. Menderes hükümetlerinin tarafsızlık siyasetinin Sovyetler Birliği'nin işine yarayacak bir yol olduğu düşüncesinde olduğu için, bu oluşumun önemini kavrayamadığ $\breve{1}$ eleştirisini getirmiştir. ${ }^{59}$ Tarafsızlık siyasetine yeni yönetimin anlayışla yaklaşarak bu ülkelerle işbirliğini güçlendirmesi gerektiği görüşünü ileri sürmüştür.

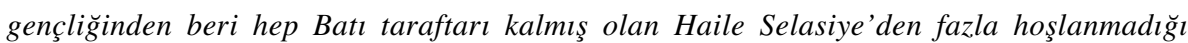

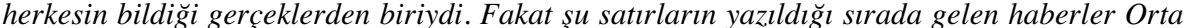
Doğ u devletlerini sarsan yeni cereyanların Habeşistann'da daha krallar kralını yerinden oynatacak kadar kuvvetlenmediğini gösteriyordu. Haile Selasiye Habeșistan'a döner dönmez duruma hâkim olmaya başlamış ve asileri kaçmaya mecbur etmişti. Veliahdın durumuna gelince, bu konuda hiçbir kesin bilgi alınamamıştı.” “ Babalar ve Oğullar”, Akis, 19 Aralık 1960, s.27.

58 "Kuruluşun Eşiğinde", Forum, 1 Aralık 1960, s. 3.

59 "Diş Politikamız Üzerine", Forum, 15 Aralık 1960, s. 1-2-3. 
Birleşik Arap Cumhuriyeti, 1961 yılında Suriye'nin çekilmesi ile ortadan kalkarken, Suriye'nin bağımsızlığını ilk tanıyan ülkelerden biri de Türkiye olmuştur. Türkiye'nin Suriye'yi tanıma kararı Mısır ile Türkiye'yi yine karşı karşıya getirmiş, Mısır Devlet Başkanı Cemal Abdün Nasır Türkiye ile diplomatik ilişkileri kesme tehdidinde bulunmuştur. Nasır'ın Ürdün'e de aynı tepkiyi göstermesi Arap Birliği’ni dağılma tehlikesi ile karşı karşıya getirmiştir. Mısır bu kararını gözden geçirerek, Suriye'nin Arap Birliği'ne dönmesine itiraz etmemiştir. Akis gelişmeleri “Nasır'ın öfke nöbetleri” olarak değerlendirmiştir.

Kasım idaresindeki Irak'ın kabinesinde komünist bakanlara yer vermesi, Sovyetler Birliği ile daha yakın işbirliği yapması Mısır ile olan ilişsilerinin bozulmasına neden olmuştur. Gelişmeleri Türk basınına Irak yönetiminin Nasır'ın kontrolünden çıkması biçiminde yansımıștır. Irak'ın Küveyt topraklarının kendisine ait olduğunu ileri sürmesi üzerine Kuveyt'te bulunan Arap ülkelerine ait askeri güçten Mısır'ın çekileceği tehdidi ile Nasır'ın kendisinin önemini hissettirmeğe çalıştığg 1 şeklide yansımıştır. Mısır'ın Suriye ve Irak ile ilişkilerinin bozulmaya başlaması, Nasır'ın bölgedeki etkisini yitirmeye başladığını, askerlerini Kuveyt'ten çekme tehdidinin bu etkiyi yeniden kazanma çabası olarak değerlendirilmiştir.

"Kahire bu kararına sebep olarak Kuveyt'teki kuvvetler arasina Mısırlıların Ürdünlülerle geçinemediklerini ileri sürmektedir. Fakat açıkça görülüyor ki bu kararın iki saiki vardır: Nasır evvela mahsur durum içinde Bağdat'a yanaşmak ve bir Băgdat-Kahire Mihveri kurmak istemistir. İkinci saik, yokluğunu Araplara hissettirmek, kendisi olmayınca hiçbir şey yapılamayacă̆ını ispata kalkışmıştır.

Fakat bütün bu jestlerin Kahireli diktatörün diline doladı̆̆ büyük Arap Birliğinin mahvı pahasına olduğunda Şüphe var mıdır? Küveyt Emiri çaresiz kalip da yine Ingilizleri davet edecek olursa, o zaman ne gibi bir durum ortaya çıkacaktır? Irak'ta petrol kumpanyaları ile müzakerelerin kesildiği şu siralarda İngilizlerin tekrar gelip Kuveyt'e yerleşmeleri Arap Birliği için pek iftihar edilecek bir manzara mı teşkil edecektir?

Abdün Nasır'ın Arap Birliği'nden ne mana murad ettiği bu son olay ile ne kadar iyi anlaşılmıştır!.." 60

Mısır lideri Nasır ile bölgede bulunan diğer Arap ülkeleri arasındaki nüfuz mücadelesi İslâm'1 devlet ve toplum hayatında yorumlama konularında da devam etmiştir. 1961'de mülkiyetin devletleştirilmesinin İslâm'a uygun olup olmadığı tartışmaları ülkelerin radyolarında propaganda mücadelesine dönüşmüştür. Nasır'ın ortaya attı̆̆g “Arap Sosyalizmi” Suudi Arabistan, Ürdün, Suriye, Irak, Mısır'da çeşitli tartışmaları başlatmıştır.

60 “Araplar”, Akis, 15 Ekim 1961, s.25. 
Suudi Arabistanlı din ulemaları Arap Sosyalizmi'ne Kur'an ve Hadis'e aykırı olduğunu savunurlarken, Irak Başbakanı Abdülkerim Kasım Cezayirlilerin aç ve çıplak mücadele ederlerken Arap şeyhlerinin altın içinde yüzmelerinden bahsetmesi, Nasır'ın Arap Sosyalizmine destek verdiğinin işareti olarak anlaşılır. Nasır tepkilere karşı Mısır'da İslami Tetkikler Akademisi açılacağını, bütün mezhep ve tarikatların en yetkili mümessillerini bir araya getirerek “Kuran'ın aydınlığında günümüzün ekonomik ve sosyal doktrinleri incelenecektir"61 açıklamasını yapmıştır. Akis tartışmaları monarşik ve feodal rejimlerin Nasır'ın siyasetinden duydukları endişeden ileri geldiğini görüşüne yer vermiştir. Arap ülkelerinin dini siyasete alet etmede yalnızca ülkeleri sınırları içinde kalmadıklarını, uluslararası alana taşıma gayretleri içinde olduklarını, bunu yapanların yalnızca monarşi ve feodalitenin değil, aynı zamanda Abdün Nasır'ın Sosyalist Devrim adıyla yaptıklarının diğerlerinden farkı olmadığını ${ }^{62}$ yazmışır. ${ }^{63}$

20 Aralık 1961'de Doğan Avcıoğlu'nun çıkardığı Yön dergisi yayın hayatına başlarken dergi yedinci sayısından itibaren Mısır Lideri Nasır'ın ülkesinde gerçekleştirdiği değişimi yazı dizisi halinde vermeye başlamıştır. Yazılar genellikle yabancı basından gazetecilerin Nasır ile yaptığ söyleşilerin çevirisi biçiminde verilmiştir. Nasır'ın politikası başarılı bulunurken, sosyalizmin üçüncü dünya ülkelerinde ulaştığ 1 başarılar olarak yansıtılmıştır. Nasır'ın başkanlığa geldiği 1954'ten beri Türk basınında olumlu bir değerlendirme yapılmazken Yön dergisi adeta Nasır'a adeta itibarını iade ediyordu. Nasır'ın Mısır için izlediği politika örnek olarak gösterilmiş, ilk sayıda Mısır'ın tarım politikası anlatılmış, "Nasır'ın Mısır Sosyalizmi" ${ }^{64}$ başlığıyla verilmiştir. 26. Sayısında ise Arap Sosyalizmi'nin tarihini Batı'ya Batı'daki gelişmelere bağlamanın yanlış olduğu tezi savunulurken, Arap Sosyalizmi'nin kaynaklarının Arapların kendi tarihinde mevcut olduğu yönünde bir değerlendirme yapılmıştır. ${ }^{65} \mathrm{Az}$ gelişmiş ülkelerde kalkınmanın sağlanabilmesi için Birleşik Arap Cumhuriyeti'nde hedeflerini Lübnan'da yayınlanan Arap Observer dergisinden alıntılar yaparak Türk okuyuculara anlatan dergi Nasır'ın hedeflerini ${ }^{66}$ sadece Misır açısından değil bütün Arap dünyası açısından, hatta az gelişmiş bütün ülkeler için bir model olarak sunmuştur. Bir başka sayısında "Arap Birliği” başlı̆̆g altında yazıda Nasır'ın uygulamaya koyduğu programlar Orta Doğu'nun

61 “Araplar, Yeni Mücadele”, Akis, 27 Kasım 1961, s.21.

62 "Araplar: Yeni Mücadele", Akis, 27 Kasım 1961, s.21.

${ }^{63}$ Bkz. Mısır'Da, Nasır'ın ortaya attı̆̆ 1 Arap Milliyetçiliği ve Arap Sosyalizmi konusunda incelemeler yapılmıştır. Zeynep Güler; Süveyș'in Batısında Arap Milliyetçiliğ̈i, Misır ve Nasircılık, Yenihayat Yayıncılık, İstanbul, 2004. s.267.

${ }^{64}$ Kingsley Martin; "Nasır Misır Sosyalizmini Anlatiyor: Kooperatiflerin Kurulması Tarımda Verimi Arttırmıștır", Yön, 31 Ocak 1961, s. 19.

65 “Arap Sosyalizminin Kaynakları”, Yön, 13 Haziran 1962, s.15.

${ }^{66}$ “Nasir' In Hedefleri”, Yön, 4 Temmuz 1962, s.16. 
ezilen, sömürüler halkları için sosyalizm projesi olarak anlatılmıştır. ${ }^{67}$ Yön dergisinde Nasır'a ilişkin yazılar 24 Ekim, 3 Ekim, $14 \mathrm{Kasım}^{68}$ tarihli sayılarında yayınlanmıştır. Yayınlanan yazılarda Nasır'a ilişkin olumsuz bir yazı olmadığı gibi görüşleri ve uygulamaları azgelişmiş ülkelerin ekonomik ve siyasal sorunlarını çözecek çare olarak anlatılmıştır. Yazılarda "Başkan Nasır" olarak anılmıştır. Nasır, Türk basınında sürekli eleştirilirken Yön dergisinde tam tersine eleştiri bir yana hem teorisyen hem de uygulayıcı bir kişilik olarak ele alınmıştır.

Mısır lideri Cemal Abdün Nasır, ülkesinin lideri olarak kalmamış Orta Doğu'da özellikle Arap halkı üzerinde etkili bir kişilik olmuştur. Türkiye'de diğer ülkelerle olduğu gibi dış politika konusunda özellikle ellili yılların ilk yarısında basında hükümetlerin dış siyaseti eleştirilmemiştir. 1957'den itibaren muhalefet yanlısı basından, dış siyasete ilişkin eleştiriler Bağdat Paktı ve Balkan Paktı'nın başarısızlığa uğradığı ölçüde gelmeye başlamıştır. Şüphesiz bu yıllarda Misır-Türkiye ilişkisi sorunlu bir seyir izlerken, Orta Doğu'da sorunların kaynağına genellikle Nasır oturtulmuştur. 1962'den itibaren basında Nasır ile ilgili eleştirel bakıș açısı devam ederken, Yön dergisi Nasır'ı bir kurtarıcı olarak değerlendirmiş, izlediği iç ve dış politikasının bölge ülkeleri için de örnek oluşturduğunu ileri sürmüştür.

Yirminci yüzyılda Orta Doğu dünyanın en önemli bölgelerinden biri olurken günümüze kadar çatışmaların devam ettiğine tanıklık etmekteyiz. Bölgedeki mücadelelerde çatışmanın tarafları bölge halkları ile Batılılar olurken, bölge ülkeleri bağımsızlık mücadelelerinde birbirlerini desteklerken, zaman zaman aralarında çıkar çatışmaları yaşanmıştır. ${ }^{69} \mathrm{Bu}$ çıkar çatışmalarında Türkiye ile Arap ülkelerinin anlaşamadığg konular zamana ve koşullara göre değişmesine rağmen sıcak bir çatışmaya varmamıştır. Suriye ve Mısır'ın birleşerek Birleşik Arap Cumhuriyeti adı altında yaklaşık üç yıl tek devlet olarak varlığını sürdürmesinin yanında Türkiye ile Mısır'ı sınır komşusu yapmıştır. Anılan dönem Araplar arasında

\footnotetext{
67 “Arap Birliği”, Yön, 5 Eylül 1962, s.17.

${ }^{68}$ Nasır'in dis siyaset konusunda görüsslerine yer verilirken sömürgeciliğe karşı olduğu vurgulanmıştır. Misır'ın tarihsel olarak sömürge karşıtı mücadeleler verdiğini osmanlı karşıtlığıyla anlatmıştır.

«Mısır halkı, sömürgeciliğe karșı mücadesinde milletlerin mücadele tarihinde bu güne kadar destani özelliğini muhafaza eden canlı bir örnek vermiştir.

Halkımız Osmanlı sömürgeciliğinin maskesini düşürmüs ve yenmistir. Hemde bu sömürgecilik İslam halifeliği peçesi altında gizlendiği halde. Halkımız daha sonra Fransı istilasına karşı direnmiş böylelikle Avrupayı dize getiren macerecı Fransa'yı kaçmak için gece yarısı Akdenize açlmaya mecbur etmistir.

Halkımız daha sonra dünya emperyalizminin ve milletlerarası tekellerin komplolarına karşı koymuştur. Bunlar amaçlarına erişebilmek için Mehmet Ali sülalesinden yararlanmışlardır.» "Geri Kalmışlık ile Gelişmişlik Arasındaki Çatışma Dünya Barışı Açısından Tehlikedir », Yön, 14 Kasım 1962, s.16.

${ }^{69}$ Cengiz Çandar; Ortadoğu Çıkmazı; Hil Yayınları, İstanbul, 1983. s. 10.
} 
Nasır'ın etkili olması ve Nasır'ın Türkiye'deki olumsuz algılanması, basında olumsuz yorumların yapılmasına neden olmuştur.

\section{SONUÇ}

Soğuk Savaş Dönemi'nde Sovyetler Birliği’nin tehditlerine maruz kalan Türkiye, ABD ve İngiltere'nin desteğini alarak Orta Doğu ülkeleri ile ilişkilerini geliştirmek istemiş, hatta Sovyetler Birliği'nin güneyindeki ülkelerde ve Akdeniz'de yayılmasının önüne geçmek için Orta Doğu Savunma Komutanlığı, Akdeniz Komutanlığı girişimlerinden sonra Bağdat Paktı'nın kurulmasını gerçekleştirmiştir. Türkiye'nin Arap ülkelerindeki mevcut yönetimlerle işbirliğini geliştirme çabasında başlıca iki engelle karşılaşmıştır. Birincisi Türkiye'nin bölgede Sovyetler Birliği'ni nasıl tehdit olarak algılıyorsa, İngiltere ve İsrail bölgede aynı ölçüde tehdit olarak algılanmıştır. Oysa Türkiye'nin bölge için geliştirdiği siyasette İngiltere etkin bir rol oynamaktadır. İkincisi, bölge ülkelerinin halkları arasında Arap milliyetçiliği güç kazanmakta, yükselen milliyetçilik dalgası Türkiye'nin işbirliği yaptığı yönetimleri tehdit etmektedir. Nihayetinde Bağdat Paktı'nın önemli bir ayağını oluşturan Irak'ta yönetim değişikliği paktın sonunu getirmiştir.

Mısır'da 1952'de meydana gelen yönetim değişikliğinden sonra Nasır'ın uzun yıllar sürecek olan iktidarı süresince bölgesi ve ülkesi için izlediği politika ile Türkiye'nin izlediği politika örtüşmezken, bölge halkları üzerinde etkili bir isim olmuştur. Örneğin Başbakan Menderes bölge ülkelerini ziyaretinde Nasır yanlısı gösterilere tanık olurken, yaptığı konuşmalarda dolaylı olarak Nasır'ı eleştirmiştir.

Her iki ülkenin basın yayın organlarında karşılıklı suçlamalar ve eleştiriler eksik olmazken, özellikle 1958 'de Irak'ta yapılan askerî müdahaleden sonra, Türkiye'de muhalif basın hükümetin dış politikasını açıkça eleştirmeye başlamıştır. Orta Doğu ülkelerinde meydana gelen iktidar değişiklikleri ve diğer gelişmelerde, gazete ve dergilerin dış politika konusundaki eleştirileri Menderes hükümetlerinin başarısızlıklarına örnek gösterilmiştir. Basında Nasır ile ilgili olumsuz değerlendirmeler devam etmesine rağmen, Nasır'ın bölge halkı üzerinde Arap milliyetçiliği ile ilgili propagandasının başarılı olduğu yazarların yorumlarında vurgulanmaya başlanmış, Türk hükümetlerinin gelişmeleri sağlıklı değerlendiremediği şeklinde görüşler öne sürülmüştür. 27 Mayıs Askerî Müdahalesi’nden sonra 1962'den itibaren yayınlanmaya başlayan Yön dergisi ise Nasır'ın islediği siyaseten başarılarından söz edilerek, az gelişmiş ülkelerde uygulanması gereken sosyalist hareket olarak "Nasır Sosyalizmi" biçiminde değerlendirilmiştir. Bu tarihten sonra Türkiye'de hükümetlerin dış politikası en az iç politika kadar eleştiri konusu yapılmaya başlanmıştır. 


\section{KAYNAKÇA}

Armaoğlu, Fahir; 20. Yüzyıl Siyasî Tarihi (1914-1980), Türkiye İş Bankası Yayınları, Ankara, 1989.

Avcıoğlu, Doğan ;'’Bağdat Paktı Meselesine Dair', Akis, 19 Ocak 1957.

Avcıoğlu, Doğan; “Orta Doğudaki Soğuk Harp”, Akis, 9 Şubat 1957.

Balkan, Aydemir; “Arap Kardeşlerimiz Masalı”, Kim, 14 Kasım 1958.

Balkan, Aydemir; “Arapları Artık Aldatabilir miyiz?” Akis, 27 Temmuz 1957.

Balkan, Aydemir; “Dış Politikada Vazifeler” Akis, 20 Temmuz 1957.

Balkan, Aydemir; "Dostları Azalan Bir Memleket”, Akis, 10 Mart 1956.

Çandar Cengiz; Ortadoğu Çıkmazı, Hil Yayınları, İstanbul, 1983.

Çavdar, Tevfik; Türkiye'nin Demokrasi Tarihi 1839-1950, İmge Kitabevi, Ankara, 1995.

Davişa, Adid; Arap Milliyetçiliği Zeferden Umutsuzluğa, Çev. Lütfi Yalçın, Literatür Yayınları, İstanbul 2004.

Dikerdem, Mahmut; Ortadoğu'da Devrim Yılları (Bir Büyükelçinin Anıları), İstanbul, 1977.

Dr. İlhan Faik; Süveyş Kanalı'nın Hukuki Hikâyesi, Akis, 4 Ağustos 1956.

Ecevit, Bülent; “ Arap Milliyetçiliği ve Batı”, Kim, 25 Temmuz 1958.

Ecevit, Bülent; “Arap Milliyetçiliği ve Batılılar”, Ulus, 15 Mart 1957.

Ecevit, Bülent; “İktidar ve Muhalefet”, Ulus, 20 Aralık 1957.

Ecevit, Bülent; “Ortadoğu Çıkmazı”, Ulus; 5 Ocak 1957.

Ecevit; “Arap Milliyetçiliği ve Türkiye”, Akis, 10 Ocak 1957.

Ergüder, Özcan; “Kıbrıs”, Kim, 28 Haziran 1958.

Ergüder, Özcan; "Yanlışlıklar Komedisi”, Kim, 25 Temmuz 1958.

Esmer Ahmet Şükrü; “Mısır’da Yeni Rejim”, Ulus, 20. 01. 1956.

Esmer, Ahmet Şükrü; “Dış Politika”, Ulus, 1 Ocak 1956.

Fenik, Mümtaz Faik Fenik; “Menderes Açık Kalple Konuştu”, Zafer, 8 Şubat 1955.

Fenik, Mümtaz Faik; “Bağdat Paktının İmzası”, Zafer, 25 Şubat 1955.

Fenik, Mümtaz Faik; “Türkiye ve Misır”, Zafer, 23 Ocak 1955. 
Güler Zeynep; Süveyş’in Batısında Arap Milliyetçiliği Mısır ve Nasırcılık; Yeni hayat Yayınları, İstanbul, 2004.

Gönlübol Mehmet ve Ömer Küçükoğlu; Olaylarla Türk Dış Politikası, SBF Yayınları, Ankara, 1987.

İleri, Rasih Nuri; Örtülü Ödenek, Scala Yayıncılık, İstanbul, 1996.

Kaya, Şükrü; “Görüşler: Orta-Doğu Hakkında Rus Notaları ve Cevapları”, Hürriyet, 17 Haziran 1957.

Kırca, Coşkun; “ Türkiye ve Birleşik Amerika”, Kim, 12 Eylül 1958.

Kingsley Martin; "Nasır Misır Sosyalizmini Anlatıyor: Kooperatiflerin Kurulması Tarımda Verimi Arttırmıştır”, Yön, 31 Ocak 1961.

Sever Ayşegül; Soğuk Savaş Kuşatmasında Türkiye, Batı ve Orta Doğu 1945-1958, Boyut Kitapları, İstanbul, 1997.

Topalak Mücahit; Ankara Toplantısı; Akis,_ 17 Temmuz 1954.

Yalçın, Hüseyin Cahit; “Batı İli Doğu Arasında Türkiye”, Ulus, 14 Şubat 1957.

Yılmaz, Mustafa, Doğner; Yasemin; Cumhuriyet Döneminde Sansür 1923-1973), Siyasal Kitabevi, Ankara, 2007.

\section{Dergiler}

Akis

Forum

Kim

Yön

\section{Gazeteler}

Hürriyet

Ulus

Zafer 